\title{
Testing emissions of passenger cars in laboratory and on-road (PEMS, RDE)
}

\begin{abstract}
In the present paper, the results and experiences of testing different PEMS on the chassis dynamometer and on-road are presented. In the first part of work the measuring systems were installed on the same vehicle (Seat Leon 1.4 TSI ST) and the results were compared on the chassis dynamometer in the standard test cycles: NEDC, WLTC and CADC. In the second part of work the nanoparticle emissions of three Diesel cars were measured with PN-PEMS. PN-PEMS showed an excellent correlations with CPC in the tests on chassis dynamometer and it indicated very well the efficiency of DPF in eliminating the nanoparticles in real world driving.
\end{abstract}

Key words: PEMS, RDE, HD-vehicles and LD-vehicles

\section{Introduction}

PEMS - portable emissions measuring systems were introduced in the last stage of exhaust gas legislation for HD-vehicles in order to measure and to limit the real driving emissions (RDE). PEMS were also confirmed by EU to be applied for the LD-vehicles in the next legal steps.

In the present paper, the results and experiences of testing different PEMS on the chassis dynamometer and on-road are presented.

The investigated PEMS were: Horiba OBS ONE, AVL M.O.V.E and OBM Mark IV (TU Wien). In the first part of work the measuring systems were installed on the same vehicle (Seat Leon 1.4 TSI ST) and the results were compared on the chassis dynamometer in the standard test cycles: NEDC, WLTC and CADC. As reference, the results of the stationary laboratory equipment (CVS and Horiba MEXA 7200) were considered. In the second part of work the nanoparticle emissions of three Diesel cars were measured with PN-PEMS.

For the real-world testing a road circuit was fixed: approximately $1 \mathrm{~h}$ driving time with urban/rural and highway sections.

Comparisons of results between the PEMS and with stationary reference system show different tendencies, depending on the considered parameter $\left(\mathrm{NO}_{\mathrm{x}}, \mathrm{CO}, \mathrm{CO}_{2}\right)$ and on the test cycles. In this respect all investigated PEMS show similar behavior and regarding over average of all parameters and tests no special preferences or disadvantages can be declared.

Repeated test on the same road circuit produce dispersing emission results depending on the traffic situation, dynamics of driving and ambient conditions. Also the calculated portions of urban, rural and highway modes are varying according to the traffic conditions.

PN-PEMS showed an excellent correlations with CPC in the tests on chassis dynamometer and it indicated very well the efficiency of DPF in eliminating the nanoparticles in real world driving.

\section{Tested vehicles}

The comparisons of different PEM's in the first part of work were performed on the test vehicle Seat Leon 1.4 TSI (GDI, TWC) in used state (11/2 year, 20'800 km). During the tests approximately $2000 \mathrm{~km}$ were driven.
The above mentioned vehicle is presented in Fig. 1 and Tab. 1. The gasoline used was from the Swiss market, RON 95, summer quality, according to SN EN228.

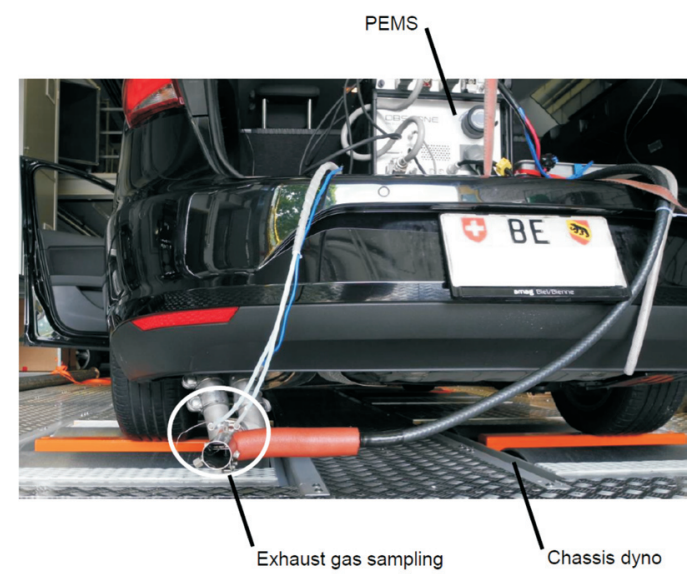

Fig. 1. Test vehicle with installed PEMS on chassis dynamometer

Table 1. Data of tested gasoline (GDI) vehicle

\begin{tabular}{|l|c|}
\hline Vehicle & SEAT Leon 1.4 TSI ST \\
\hline Number and arrangement of cylinder & 4 / In line \\
\hline Displacement $\mathrm{cm}^{3}$ & 1395 \\
\hline Power kW & $103 @ 4500-6000 \mathrm{rpm}$ \\
\hline Torque Nm & $250 @ 1500-3500 \mathrm{rpm}$ \\
\hline Injection type & Direct Injection (DI) \\
\hline Curb weight kg & 1275 \\
\hline Gross vehicle weight kg & 1840 \\
\hline Drive wheel & Front-wheel drive \\
\hline Gearbox & M 6 \\
\hline First registration & 21.01 .2014 \\
\hline Exhaust & Euro 5b \\
\hline
\end{tabular}

In the present tests the lube oil was not changed, or analyzed - the same oil was used for all tests.

The measurements with PN-PEMS in the second part of work were performed on different Diesel passenger cars. The most important data from three vehicles are presented in Table 2. 
Table 2. Data of tested Diesel vehicles

\begin{tabular}{|l|c|c|c|}
\hline & Vehicle 1 & Vehicle 2 & Vehicle 3 \\
\hline Engine & $\mathrm{R} 4$ & $\mathrm{R} 4$ & $\mathrm{R} 4$ \\
\hline Displacement cc & 1560 & 2143 & 1994 \\
\hline Gear box & $\mathrm{m} 6$ & $\mathrm{a} 5$ & $\mathrm{~m} 5$ \\
\hline First registration & 2015 & 2010 & 1998 \\
\hline Exhaust & Euro 6b & Euro 5a & Euro 2 \\
\hline Aftertreatement & DPF & DPF & - \\
\hline
\end{tabular}

\section{Test equipment}

Part of the tests were performed on the 4WD-chassis dynamometer of AFHB (Laboratory for Exhaust Emission Control of the Bern University of Applied Sciences, Biel, CH).

The stationary system for regulated exhaust gas emissions is considered as reference.

This equipment fulfils the requirements of the Swiss and European exhaust gas legislation.

- regulated gaseous components:

exhaust gas measuring system Horiba MEXA-7200

$\mathrm{CO}, \mathrm{CO}_{2} \ldots \quad$ infrared analysers (IR)

HCFID... flame ionisation detector for total hydrocarbons

$\mathrm{CH}_{4}$ FID... flame ionisation detector with catalyst for only $\mathrm{CH}_{4}$

$\mathrm{NO} / \mathrm{NO}_{\mathrm{x}} \ldots \quad$ chemoluminescence analyser (CLA)

The dilution ratio DF in the CVS-dilution tunnel is variable and can be controlled by means of the $\mathrm{CO}_{2}$-analysis.

\section{Nanoparticle analysis}

The measurements of summary particle counts in the size range 23-1000 $\mathrm{nm}$ were performed with the CPC TSI 3790 (according to PMP).

For the dilution and sample preparation an ASET system from Matter Aerosol was used (ASET ... aerosol sampling and evaporation tube). This system contains:

- Primary dilution air - MD19 tunable minidiluter (Matter Eng. MD19-2E).

- Secondary dilution air - dilution of the primary diluted and thermally conditioned measuring gas on the outlet of evaporative tube.

- Thermoconditioner (TC) - sample heating at $300^{\circ} \mathrm{C}$.

As a portable system for on-road application the $\mathrm{Na}$ noMet 3-PS from Matter Aerosol-TESTO (NM3) was used. The sample preparation, as described above, is integrated in this analyzer and it indicates the nanoparticles in the size spectrum 10-700 $\mathrm{nm}$.

The overview of used PEMS is given in the Table 3. Let us remark that the OBM Mark IV system does not use any flowmeter for exhaust flow measurement. It calculates the necessary parameters from the on-board data. Thanks to that this apparatus can be much simpler and quicker adapted on the vehicle.

\section{Test procedures}

\section{Driving cycles on chassis dynamometer}

The vehicle was tested on a chassis dynamometer in the dynamic driving cycles: NEDC, Fig. 2, WLTC, Fig. 3 and CADC, Fig. 4.
Table 3. Overview of used measuring systems

\begin{tabular}{|c|c|c|c|c|}
\hline & $\begin{array}{c}\text { HORIBA } \\
\text { MEXA } 7100\end{array}$ & $\begin{array}{l}\text { HORIBA } \\
\text { OBS ONE }\end{array}$ & $\begin{array}{c}\text { AVL } \\
\text { M.O.V.E }\end{array}$ & $\begin{array}{c}\text { TU Wien OBM } \\
\text { Mark IV }\end{array}$ \\
\hline & $\begin{array}{l}4 \times 4 \text { chassis } \\
\text { dyno CVS }\end{array}$ & $\begin{array}{l}\text { PEMS (1) } \\
\text { wet }\end{array}$ & $\begin{array}{l}\text { PEMS (2) } \\
\text { dry }\end{array}$ & $\begin{array}{c}\text { PEMS (3) } \\
\text { dry }\end{array}$ \\
\hline $\mathrm{CO}$ & NDIR & $\begin{array}{l}\text { heated } \\
\text { NDIR }\end{array}$ & NDIR & NDIR \\
\hline $\mathrm{CO} 2$ & NDIR & $\begin{array}{l}\text { heated } \\
\text { NDIR }\end{array}$ & NDIR & NDIR \\
\hline $\mathrm{NO}_{\mathrm{x}}$ & CLD & CLD & NDUV & $\begin{array}{l}\text { Zirkonium- } \\
\text { dioxid }\end{array}$ \\
\hline NO & CLD & CLD & - & $\begin{array}{c}\text { Electrochemical } \\
+ \text { NDIR }\end{array}$ \\
\hline $\mathrm{NO}_{2}$ & calculated & calculated & NDUV & - \\
\hline $\mathrm{O}_{2}$ & - & - & $\begin{array}{l}\text { electro-che- } \\
\text { mical }\end{array}$ & $\begin{array}{l}\text { electro- } \\
\text { chemical }\end{array}$ \\
\hline $\mathrm{HC}$ & FID & - & IR & IR \\
\hline PN & not measured & - & - & - \\
\hline $\begin{array}{l}\text { OBD } \\
\text { logger }\end{array}$ & - & yes & yes & $\begin{array}{c}\text { yes (Bluetooth } \\
\text { dongle) }\end{array}$ \\
\hline $\begin{array}{l}\text { GPS } \\
\text { logger }\end{array}$ & - & yes & $\begin{array}{l}\text { yes (Garmin } \\
\text { GPS16) }\end{array}$ & $\begin{array}{l}\text { yes (GPS - Blu- } \\
\text { etooth receiver) }\end{array}$ \\
\hline $\begin{array}{l}\text { ambient } \\
(\mathrm{p}, \mathrm{T}, \mathrm{H})\end{array}$ & yes & yes & yes & no \\
\hline EFM & - & pitot tube & $\begin{array}{c}\text { pitot tube } \\
\text { (SEMTECH- } \\
\text { EFM HS) }\end{array}$ & no \\
\hline $\begin{array}{l}\text { PN } \\
\text { OBD } \\
\text { EFM } \\
\text { OBS-one } \\
\text { AVL Mov }\end{array}$ & \multicolumn{4}{|c|}{$\begin{array}{l}\text { - Particles Number } \\
\text { - On Board Diagnostics } \\
\text { - Exhaust Flow Meter } \\
\text { - } \mathrm{H}_{2} \mathrm{O} \text { monitored to compensate the } \mathrm{H}_{2} \mathrm{O} \text { interference on } \mathrm{CO} \text { and } \mathrm{CO}_{2} \\
\text { sample cell heated to } 60^{\circ} \mathrm{C} \\
\text { ove - dry to wet correction applied }\end{array}$} \\
\hline
\end{tabular}

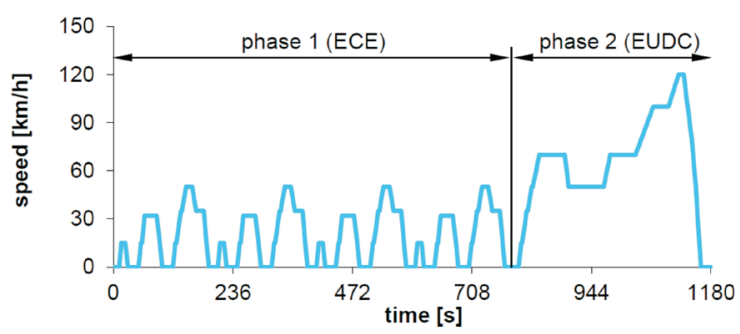

Fig. 2. NEDC European driving cycle

The first NEDC of each test series was performed with cold start $\left(20-25^{\circ} \mathrm{C}\right)$ and further cycles followed with warm engine. Between the cycle always 3 minutes of constant speed $80 \mathrm{~km} / \mathrm{h}$ in $4^{\text {th }}$ gear were performed as conditioning.

The braking resistances were set according to legal prescriptions they were not increased i.e. responded to the horizontal road.

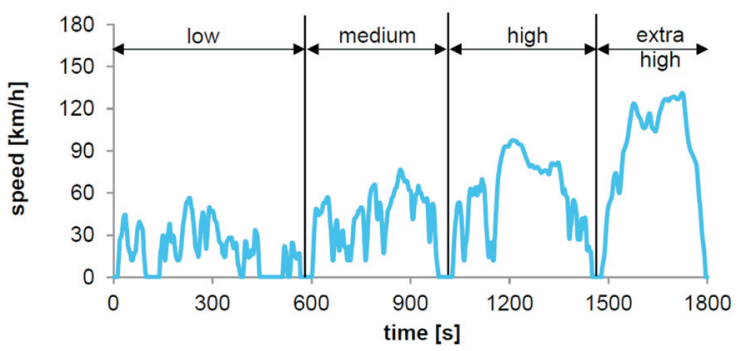

Fig. 3. WLTC driving cycle 


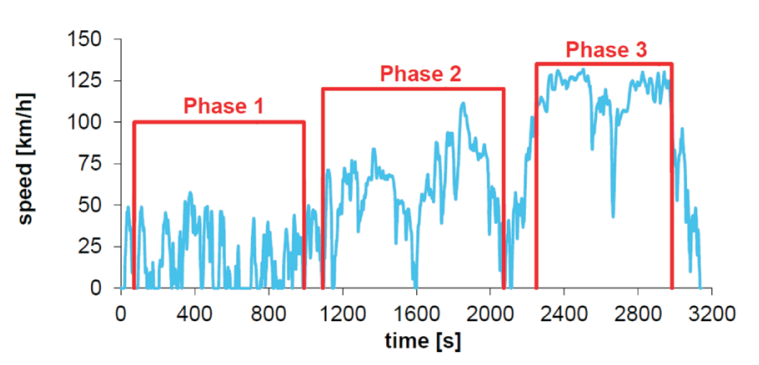

Fig. 4. CADC driving cycle

\section{On-road testing}

With each PEMS several road tests were performed. The used road circuit was always the same with approximately $1 \mathrm{~h}$ duration and parts of urban, rural and highway roads (see Fig. 8).

\section{Results}

Comparisons of PEMS on chassis dynamometer

The correlations of emissions measured with all three PEMS and with "CVS" in all driving cycles are represented in Fig. 5.

The correlations for $\mathrm{NO}_{\mathrm{x}}$ and $\mathrm{CO}$ are in an overall view quite good, but there is tendency of too high $\mathrm{NO}_{\mathrm{x}}$-values with PEMS2 and too high CO-values with PEMS1 and PEMS3. For $\mathrm{CO}_{2}$, which is naturally presented in much higher concentrations, than $\mathrm{NO}_{\mathrm{x}} \& \mathrm{CO}$, the deviations - too high values obtained with all PEMS - are clearly pronounced.

What can be the reasons of these deviations?

The mass flow $\left(\mathrm{m}_{\mathrm{x}}\right)$ of an emissions component " $\mathrm{x}$ " is calculated as:

$$
\begin{gathered}
\mathrm{m}_{\mathrm{x}}=\mathrm{V}_{\mathrm{exh}} \cdot \mathrm{k}_{\mathrm{x}} \cdot \rho_{\mathrm{x}} \\
{\left[\frac{\mathrm{kg}_{\mathrm{x}}}{\mathrm{s}}=\frac{\mathrm{m}_{\mathrm{exh}}^{3}}{\mathrm{~s}} \cdot \frac{\mathrm{m}_{\mathrm{x}}^{3}}{\mathrm{~m}_{\mathrm{exh}}^{3}} \cdot \frac{\mathrm{kg}_{\mathrm{x}}}{\mathrm{m}_{\mathrm{x}}^{3}}\right]}
\end{gathered}
$$

where: $V_{\text {exh }}$ - volumetric flow of exhaust gas, $\mathrm{k}_{\mathrm{x}}-$ volumetric concentration of component " $\mathrm{x}$ " in the exhaust gas, $\rho_{x}$ - density of the component " $x$ "

For dynamic measurements with PEMS in the real-world transient operation there is a challenge to well synchronize the signals of all three parameters, which are continuously changing with the operating conditions. (The instantaneous density varies with the pressure and temperature of exhaust gas).

All PEMS try to perform this synchronization as to the best, but the authors presume that this is the major reason for the indicated differences. Of course the measuring accuracy of the parameters also contributes to the results. In measurements of concentrations there are for the different PEMS's different: measuring principles, wet-dry-corrections and linearization.

In order to exclude the influence of volumetric flow $\left(\mathrm{V}_{\text {exh }}\right)$ and density $\left(\rho_{\mathrm{x}}\right)$ the concentrations of $\mathrm{CO}_{2}$ were correlated: integral averages measured with PEMS against the bag-concentrations (diluted) recalculated to the non-diluted concentrations at tailpipe. This is represented at the bottom of Fig. 6 as $\mathrm{CO}_{2}$ in [\%].
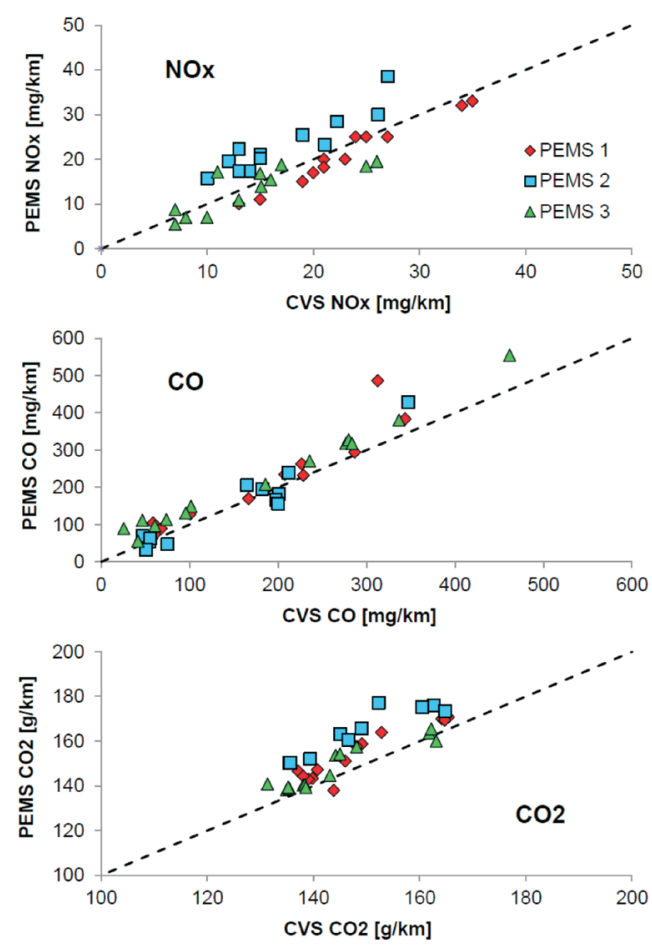

Fig. 5. Correlations of emissions measured with PEMS and with stationary CVS-installation in all investigated driving cycles: NEDC cold, NEDC, WLTC, CADC
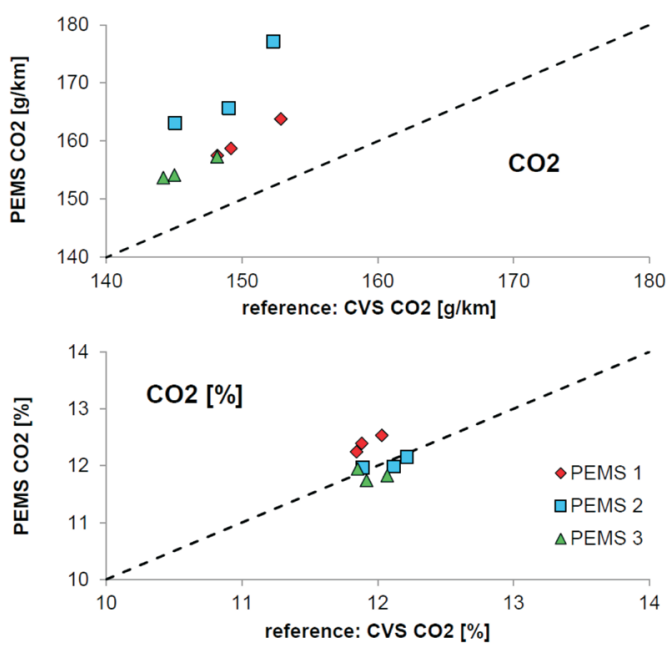

Fig. 6. Correlations of emissions measured with PEMS and with stationary CVS-installation in NEDC cold

The comparison of concentrations indicates much better correlations.

A general comparison of average results: CVS versus all PEMS's is represented in Fig. 7 for NEDCcold only and for all performed driving cycles. The higher readings with PEMS's are confirmed. $\mathrm{CO}$ and $\mathrm{NO}_{\mathrm{x}}$ have very low concentrations, so they have generally higher standard deviations, than $\mathrm{CO}_{2}$. For "all cycles" the standard deviations of $\mathrm{CO}$ are higher, because of considering the cold start cycle. 

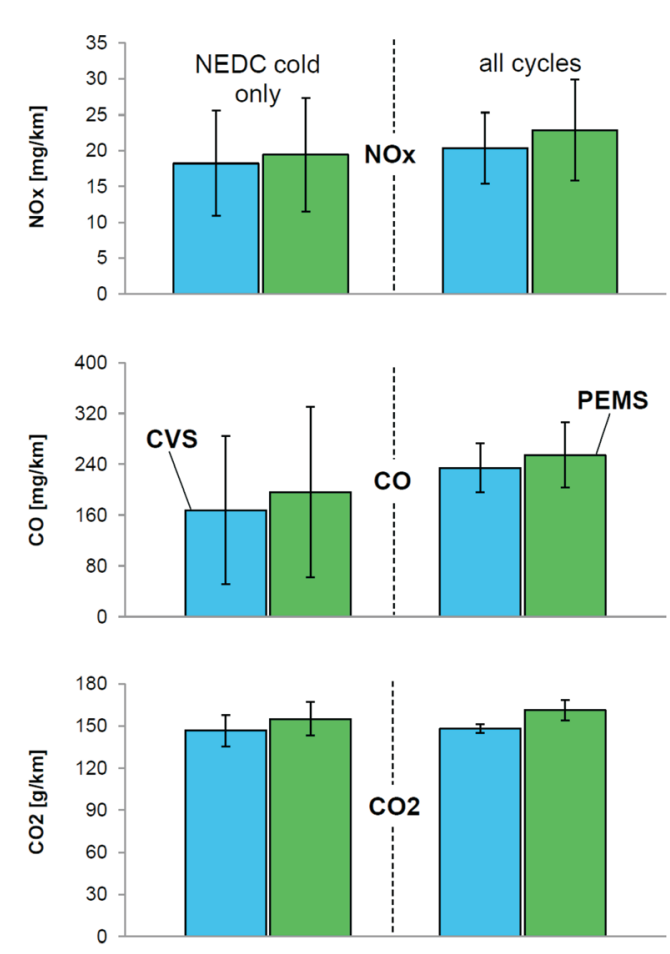

Fig. 7. Comparisons of average results: CVS versus all PEMS's

Each of the tested systems has some little and some big deviations. This conducts us to the statement that in the average view there is no best or worst system. All of them represent a similar balance of advantages and disadvantages and their measuring quality can be regarded as similar. There are of course still big potentials for improvements.

\section{$\underline{\text { Road tests and comparisons with chassis dynamometer }}$ GDI car}

The road test route used for the tests is described in Fig. 8 .

The time and the average speed in each type of (urban, rural, highway) may vary according to the traffic situation. Testing in peak traffic hours was avoided.

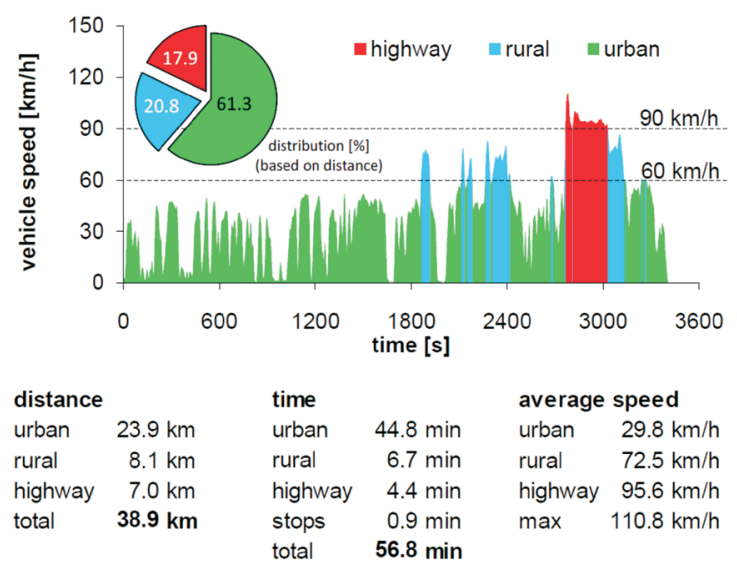

Fig. 8. AFHB Road-Test Route. PEMS 2, Seat Leon 1.4 TSI Euro 5b

The distinction between the driving modes: urban, rural, highway is performed by the evaluating program according to the RDE requirements (see next section). All cycle parts below $60 \mathrm{~km} / \mathrm{h}$ are considered as "urban" all intervals with $[60 \mathrm{~km} / \mathrm{h}<90 \mathrm{~km} / \mathrm{h}$ ] are rural and all driving with vehicle speeds $\mathrm{v}>90 \mathrm{~km} / \mathrm{h}$ is highway.

This means, that the distinction is only performed according to the driving speed and not (as usually supposed) according to the type of road.

Figure 9 shows a comparison of accumulated results from five road trips with PEMS1.
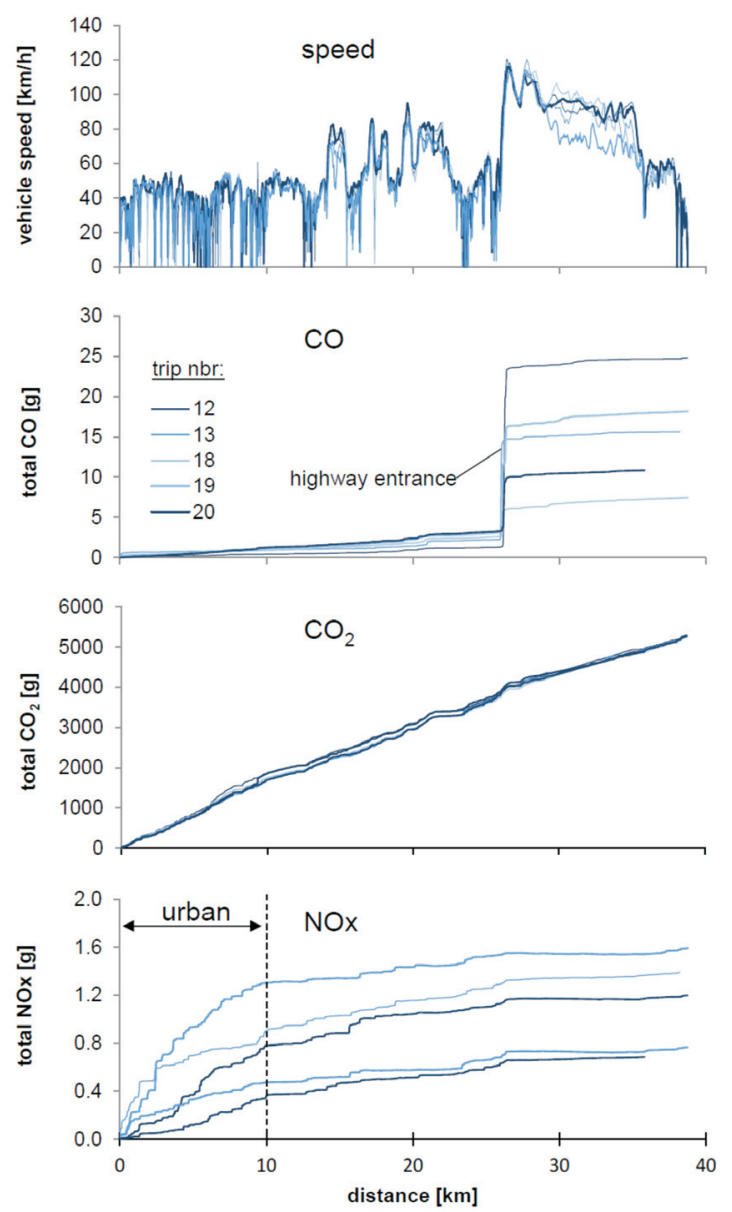

Fig. 9. Comparison of accumulated results from five road trips

From all performed trips can be followed that:

$-\mathrm{CO}_{2}$ emissions are well repetitive,

- there is a lot of dispersion in the measured $\mathrm{NO}_{\mathrm{x}}$; differences happen mainly during the first $10 \mathrm{~km}$ in the urban part of the circuit; the dynamics of driving (traffic) influences strongly the accumulated $\mathrm{NO}_{x}$,

- a CO peak occurs at the beginning of the highway part; this suddenly increasing $\mathrm{CO}$-amount during entering highway attains different levels depending on acceleration and on the initial state of engine exhaust system; this peak influences massively the accumulated end result,

- The trip composition (operation mode urban, rural, highway) is relatively constant. If there is some congestion or dense traffic on the highway parts, this can influence significantly the share between rural and highway operation.

$-\mathrm{CO}_{2}$ measurements are repetitive. 
- CO results show more dispersion - the level of CO emissions for the whole road trip is below $300 \mathrm{mg} / \mathrm{km}$, a sudden acceleration during the measurement can influence greatly the final results.

- The vehicle has not constant $\mathrm{NO}_{\mathrm{x}}$ emissions. This tendency is confirmed by the comparison of the results in different cycles with different instruments.

- $\mathrm{CO}$ and $\mathrm{NO}_{\mathrm{x}}$ measured levels are relatively low (concentrations not represented here: $\mathrm{NO}_{\mathrm{x}}$ average $<50 \mathrm{ppm} ; \mathrm{CO}$ average $<300 \mathrm{ppm}$ ).

- The results from the PEMS3, which has no EFM (Exhaust mass Flow Meter), are similar to the results of other measuring systems.

Figure 10 compares the average values from measurements performed on chassis dynamometer and in the road trips. There is a strong dispersion of $\mathrm{CO} \& \mathrm{NO}_{\mathrm{x}}$ in the road trips. This is especially caused by the quite dynamic driving style in the first part of road tests.

It can be said for $\mathrm{CO}$ and $\mathrm{NO}_{\mathrm{x}}$ that the WLTC depicts the best the average road driving in this circuit.

$\mathrm{CO}_{2}$-emissions measured on road are lower, than on chassis dynamometer.
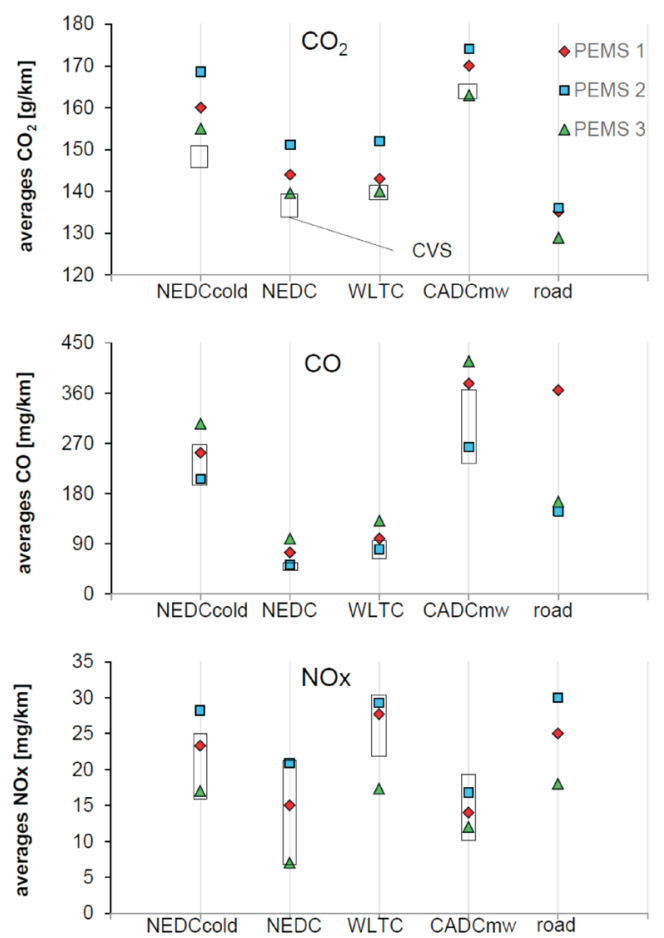

Fig. 10. Comparisons of average values between road trips and cycles on chassis dynamometer. PEMS 1, 2, 3; Seat Leon 1.4 TSI Euro 5b

\section{Testing of Diesel cars with PN-PEMS}

For these tests the PEMS (2) completed with NanoMet 3 (NM3) were used. NM3 is working on DC (diffusion charging) principle, it measures transient the particle counts emissions and is used in the EC JRC PN-PEMS Program as a "golden apparatus".

Figure 11 illustrates an example of correlation of results obtained with CPC (according to PMP) and with NM3. A very good correlation of both measuring systems is dem- onstrated. The ability of NM3 to show higher peaks during the transients and also higher average values in the driving cycles is to explain with the fact, that NM3 is more sensitive in the lowest size range below $23 \mathrm{~nm}$.

In Figure 12 emissions of $\mathrm{CO}, \mathrm{CO}_{2}$ and $\mathrm{PN}$ of a modern Diesel passenger car, measured in different test cycles on chassis dynamometer (CD) and in road circuit (RDE) are given. The driving cycle of RDE was stored and fed into the driving conductor system of the chassis dynamometer and finally performed on the chassis dynamometer with simultaneous measurements with PEMS (2) and with the stationary system (CVS). This is designated in this figure as RDE-CD.

For CO there are clearly higher values in the "cold" cycle. The repetition of the RDE-cycle on chassis dynamometer results in lower CO-values, which nevertheless was not a repetitive tendency in other repeated tests.
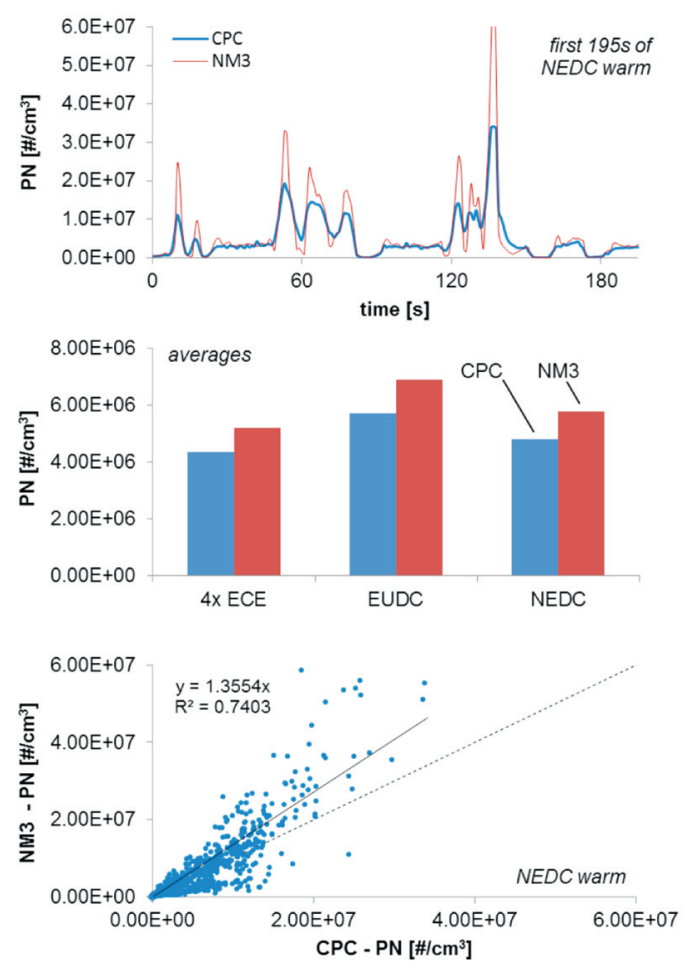

Fig. 11. Particle counts concentrations measured simultaneously at tailpipe with NanoMet 3 (NM3) and with CPC

For both components $\mathrm{CO}$ and $\mathrm{CO}_{2}$, PEMS indicates clearly higher readings $(10 \%$ to $20 \%)$ than the stationary installation with bags (CVS). This confirms the previous observations (see explanations to Fig. 5\&6).

The PN-values of this vehicle with DPF are very low (approximately 30 to 120 times lower than the actual limit value of $6.0 \times 10^{11} \# / \mathrm{km}$ ), they are at or up to 10 times below the PN background level. This impressively demonstrates the high efficiency of the DPF-technology in eliminating the nanoparticles.

Figure 13 shows in WLTC another example of DPF efficiency: vehicle 1 with a high quality DPF represents the average particle counts reduction rate (PCRR) relatively to 
the highest emitting vehicle 3 of $99.998 \%$. The damaged $\mathrm{DPF}$ is visible with PCRR $=48.786 \%$.

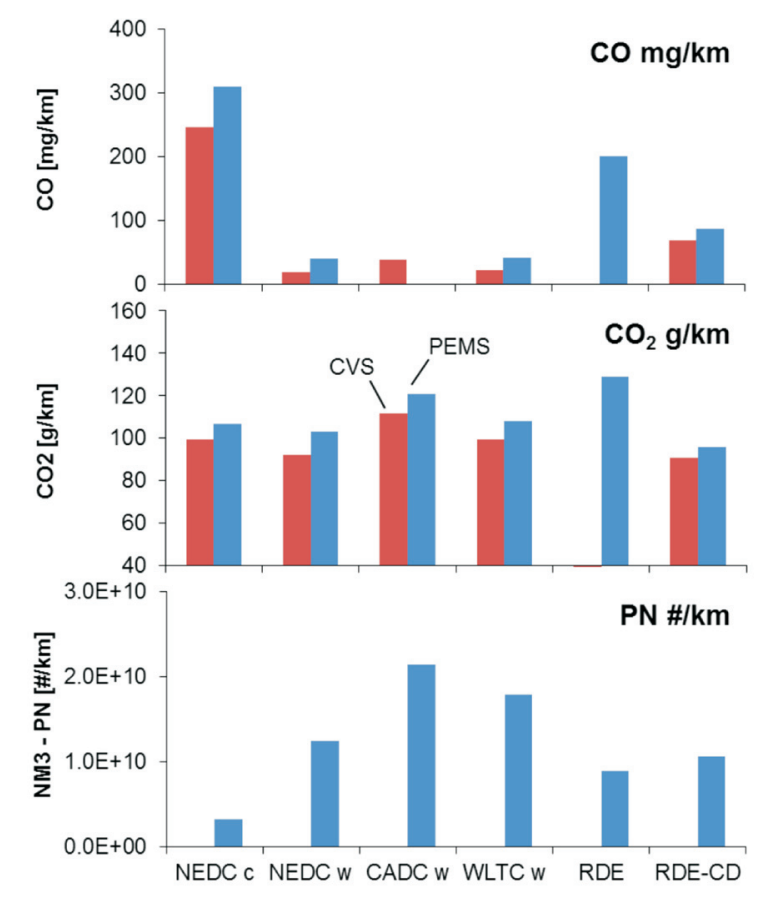

Fig. 12. Emissions of a modern diesel passenger car (Euro 6b) in different driving cycles and in real driving

\section{$\underline{\text { RDE requirements for road testing }}$}

The requirements concerning: vehicle, test circuit, test equipment, boundary conditions, emission trip validation and evaluation are given in the preliminary version of the Euro $6 \mathrm{c}$ Norm, $[1,3]$. Useful information and explanations can be found in literature, $[2,4-6]$.

The objective of this section is to give a possible short summary of the requirements of this testing method.

An extract of the requirements regarding trip validation is:

- DAQ at least at $1 \mathrm{~Hz}$

- percentage of total trip distance $(34 \%-33 \%-33 \%)$

- urban $\rightarrow$ rural $\rightarrow$ highway (continuously run)

- urban: <60 km/h; rural: $60-90 \mathrm{Km} / \mathrm{h}$; highway: $>90 \mathrm{~km} / \mathrm{h}$ $(\neq 50-80-120 \mathrm{~km} / \mathrm{h})$

- max velocity $145 \mathrm{~km} / \mathrm{h}$

- average speed in urban including stops $=15-30 \mathrm{~km} / \mathrm{h}$

- stops $=$ vehicle speed $<1 \mathrm{~km} / \mathrm{h}$

- urban stops $=$ at least $10 \%$ of the time duration of urban operation

- urban shall contain several stop periods of $10 \mathrm{~s}$ or longer

- highway speed at least $110 \mathrm{~km} / \mathrm{h}$

- highway at least 5 minutes above $100 \mathrm{~km} / \mathrm{h}$

- trip duration: 90-120 minutes

- start and end point elevation difference $<100 \mathrm{~m}$

- minimum distance of each mode (urban, rural highway) $>16 \mathrm{~km}$

- measured vehicle speed (GPS or ECU) have to be checked

- shall be conducted on working day

- off road operation is not permitted
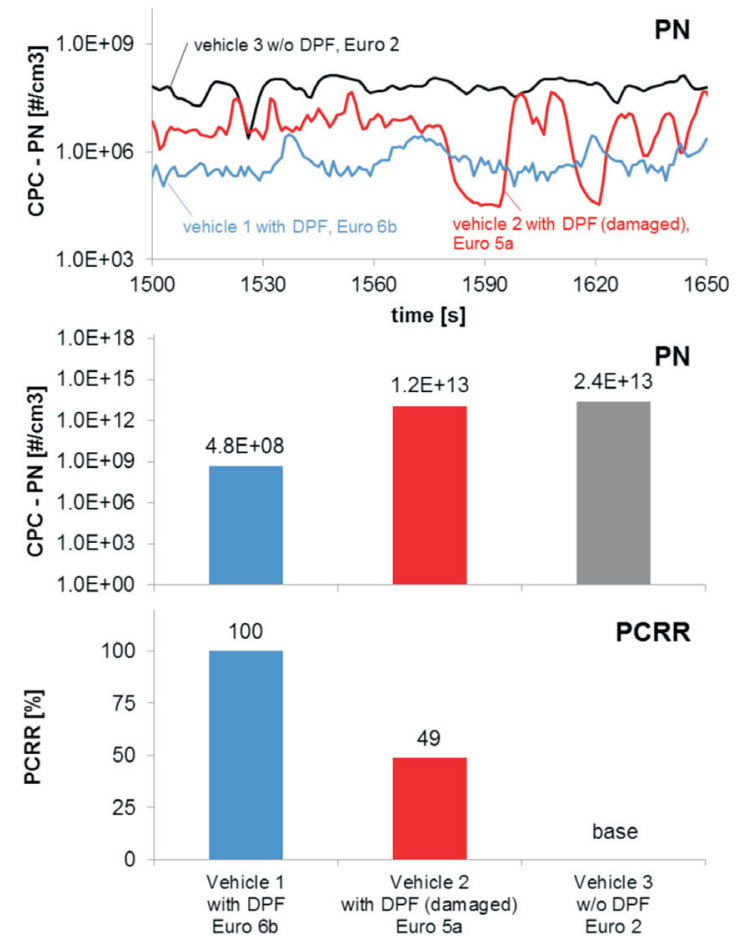

Fig. 13. Effects of DPF on Diesel Passenger Cars in WLTC (hot) Succes of DPF Technology

- it shall not be permitted to combine data of different trips of to modify or remove data from a trip

- cold start shall be recorded but excluded from the emissions evaluation $\rightarrow$ but included in trip validation

\section{Conclusions}

Following conclusions can be mentioned:

- Comparisons of PEMS's with a stationary measuring system (CVS) on a chassis dynamometer show similar behavior for all investigated instruments - different dispersion of results, depending on the considered parameter and driving cycle.

- All PEMS's indicated more $\mathrm{CO}_{2}$ than the "CVS". The reason is most probably the insufficient synchronization of the transient parameters: exhaust gas mass flow, concentration and density of the measured parameter. Further clarifications will be undertaken.

- From the road testing, it can be stated:

- $\mathrm{CO}_{2}$ emissions are repetitive,

- there is a lot of dispersion in the measured $\mathrm{NO}_{\mathrm{x}}$; differences happen mainly during the first $10 \mathrm{~km}$ in the urban part,

- a CO peak occurs at the beginning of the highway part; this peak influences massively the accumulated end result,

- the results from the OBM system (TU-Wien), which has no EFM (Exhaust mass Flow Meter), are well correlating with the results of other measuring systems.

- The PN-measuring device - NanoMet3 - is confirmed as a useful device for PEMS-application, it impressively demonstrated the efficiency of the DPF-technology in eliminating the nanoparticles. 
- There are quite numerous requirements for a trip validation of the RDE-procedures. The road traffic influences some of the validation parameters. It is recommended to select a "flexible" road circuit, which can be adapted to the actual traffic situation.

Summarizing: the PEMS and RDE testing is a new challenging task for the test laboratories.

\section{Acknowledgement}

The authors express their thanks to the Swiss Federal Office of Environment BAFU, Dr. M. Schiess and Mr. G. D'Urbano and to the Laboratories for Testing Materials, EMPA, Mr. Ch. Bach and Mr. Th. Büttler for support and collaboration.

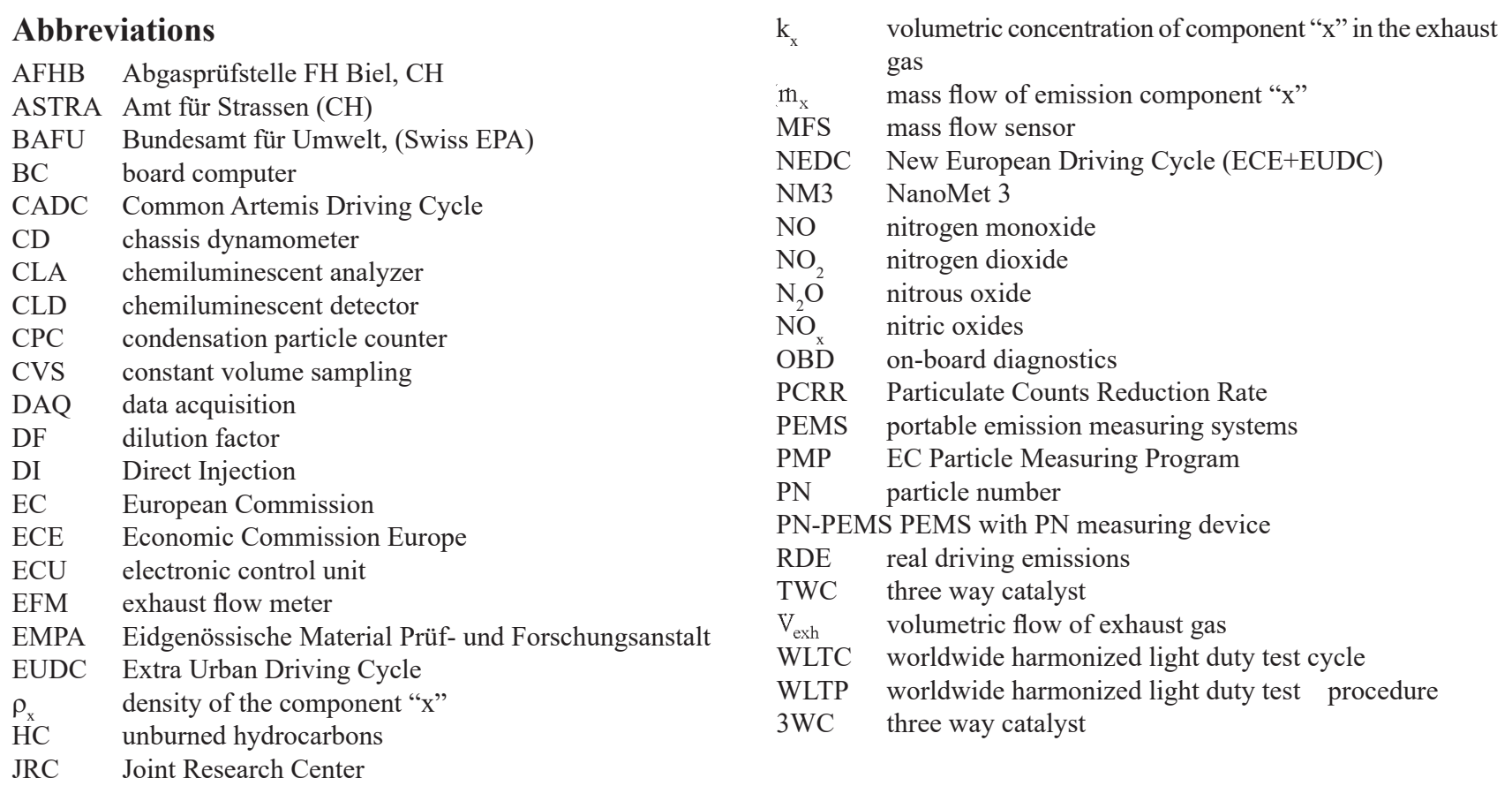

\section{Bibliography}

[1] Commission Regulation (EC) no 692/2008 of 18 July 2008 implementing and amending Regulation (EC) No 715/2007 of the European Parliament and of the Council on type-approval of motor vehicles with respect to emissions from light passenger and commercial vehicles (Euro 5 and Euro 6) and on access to vehicle repair and maintenance information. Available at: eur-lex.europa.eu/legal-content/en/ALL/?uri=CELEX:32008R0692.

[2] Brüne, H.-J., Bittermann, A., Fortner, T. RDE - The challenge for future Diesel Powertrains. 8. Internationales Forum, Abgasund Partikel-Emissionen, 1-2 April 2014, Ludwigsburg.

[3] Darft of the Annex IIIa: Verifying Real Driving Emissions

Prof. Jan Czerwiński, DEng. - Laboratorium for IC-Engines and Exhaust Gas Control, University of Applied Sciences Biel-Bienne, Switzerland.

e-mail: jan.czerwinski@bfh.ch

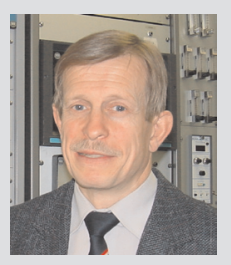

Yan Zimmerli - University of Applied Sciences, Biel-Bienne, Switzerland.

e-mail: yan.zimmerli@bfh.ch amending Regulation (EC) No 692/2008 as regards emissions from light passenger and commercial vehicles (Euro 6). Available at: ec.europa.eu/transparency/regcomitology/index.cfm keyword: D040155/01.

[4] Anderson, J., May, J., Favre, C., Bosteels, D. et al. On-Road and Chassis Dynamometer Evaluations of Emissions from Two Euro 6 Diesel Vehicles. SAE Paper 2014-01-2826.

[5] Vlachos, T.G., Bonnel, P., Weiss, M. Die Bewertung des Abgasverhaltens von Fahrzeugen im realen Fahrbetrieb - Eine Herausforderung für die europäische Emissionsgesetzgebung. 36. Internationales Wiener Motorensymposium, 2015.

[6] Hofacker, A. Abgasnorm und Wirklichkeit Eine Annäherung. Springer: MTZ-Motortechnische Zeitschrift, January 2015, Vol. 76, Issue 2, pp 8-13.

Pierre Comte - AFHB, University of Applied Sciences, Biel-Bienne, Switzerland.

e-mail:pierre.comte@bfh.ch

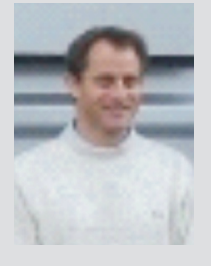

Felix Reutimann - BAFU, Federal Office of Environment, Switzerland.

e-mail:felix.reutimann@bafu.admin.ch 